\title{
УдК 01:[016:929]
}

\section{Т. Д. Байтураев}

\section{Библиография изданий Г. А. Пугаченковой как источник краеведческой библиографии}

В статье изучаются научно-вспомогательные библиографические пособия, в которых отражены издания историка искусства Узбекистана академика Г. А. Пугаченковой. Сотрудниками Института искусствознания АН Республики Узбекистан ведутся работы по созданию библиографических сводов, в которых специалисты могут найти сведения обо всех изданиях ученых. В этих биобиблиографических указателях ведется учет всей печатной продукции специалистов от первых статей ученого до фундаментальных научных публикаций данного автора. В статье анализируются принципы отбора и порядок размещения основных научных работ в библиографическом указателе. Подобные библиографические пособия позволяют проследить динамику изменения научных интересов ученого, рассмотреть его включенность в исследование той области знания, которой посвящены его публикации, выявить его творческие и научные контакты.

Ключевые слова: публикации автора, духовная культура, принципы группировки записей, биобиблиографический указатель, библиографическое пособие, научные интересы ученого, краеведческая библиография

\section{Toichu D. Bayturaev}

\section{Bibliography of G. A. Pugachenkova as a source of local history bibliography}

The article examines scientific and auxiliary bibliographic manuals, which reflect the publications of the art historian of Uzbekistan, academician G. A. Pugachenkova. Employees of the Institute of Art Studies of the Academy of Sciences of the Republic of Uzbekistan are working on the creation of bibliographic collections, in which specialists can find information about all publications of scientists. These biobibliographic indexes keep track of all printed products of specialists from the first articles of the scientist to the fundamental scientific publications of the given author. The article analyzes the principles of selection and the order of placing major scientific works in the bibliographic index. Such bibliographic aids make it possible to trace the dynamics of changes in the scientific interests of a scientist, to consider his involvement in the study of the field of knowledge to which his publications are devoted, to reveal his creative and scientific contacts.

Keywords: author's publications, spiritual culture, principles of grouping records, biobibliographic index, bibliographic guide, scientific interests of the scientist, local history bibliography

Dol 10.30725/2619-0303-2021-2-170-173

Галина Анатольевна Пугаченкова, комплексный исследователь материальной и культурной истории народов Средней Азии, родилась 7 февраля 1915 г. в Верном. После окончания средней школы в 1930 г. Галина Анатольевна поступила на архитектурный факультет Среднеазиатского индустриального института в Ташкенте по специальности «архитектура». В 1941 г. в результате исследований она защитила диссертацию на соискание ученой степени кандидата архитектуры.

С 1942 по 1960 г. работала доцентом кафедры археологии исторического факультета Среднеазиатского государственного университета. С 1960 г. Галина Пугаченкова являлась заведующим отделом истории искусств и архитектуры Института искусствознания им. Хамзы в Ташкенте.

Первое научно-вспомогательное биобиблиографическое пособие, посвященное трудам Г. А. Пугаченковой, было издано в 1965 г. в Институте искусствознания [1]. В указателе, осно- вываясь на принципе полноты, отобраны все ее работы, опубликованные к тому времени. В нем специалисты могут найти издания от самых первых научных статей ученого до фундаментальных научных публикаций. Материал в указателе размещен в хронологическом порядке, также в нем представлены редакторские работы.

Научно-вспомогательная библиография в основном предназначена для специалистов, и через издания автор восстанавливает материальную и духовную культуру древнего и средневекового периода по останкам архитектурных, искусствоведческих раритетов, обнаруженных в исторических и археологических памятниках исследуемых периодов. Данным указателем могут пользоваться научные сотрудники, ученые, магистранты, студенты и преподаватели всех учебных заведении, которые преподают курсы по истории, истории искусства, культуры, истории архитектуры, археологию, нумизматику, антропологию и других специальные дисциплины. 


\section{Библиография изданий Г. А. Пугаченковой как источник краеведческой библиографии}

Этот библиографический указатель содержит полный перечень изданий Г. А. Пугаченковой от научных книг до научных статей, отражающих результаты исследовательской работы о роли духовной культуры в формировании общей культуры Узбекистана и стран Центральной Азии.

В 1975 г. научный сотрудник Института искусствознания историк, археолог, искусствовед, кандидат исторических наук Э. В. Ртвеладзе опубликовал второе отдельное библиографическое пособие, посвященное трудам академика Г. А. Пугаченковой [2]. Составителем указателя была предпринята попытка представить полную библиографию научных работ автора, расположив их в указателе в хронологическом порядке. В библиографический справочник включены труды на узбекском, русском, английском и французском языках, изданные в нашей стране и за рубежом. Эта библиография также включает сведения об изданиях, которые она редактировала.

Расширение научных исследований автора проявляется в увеличении количества изданий по истории искусства Средней Азии. Основными видами изданий, включенных в библиографию, были научные книги и статьи, также в указателе дана библиография научно-популярных изданий и документальных фильмов, в которых ученый-искусствовед участвовала как научный консультант. Данный указатель снабжен введением, в котором дается история научных исследований Г. А. Пугаченковой, рассчитанная на широкий круг читателей. Расположение материала также дано по хронологии, внутри последней рубрики - в алфавитном порядке.

В 1985 г. научный сотрудник Института искусствознания историк, археолог, искусствовед Э. В. Ртвеладзе подготовил к изданию третий библиографический указатель по изданиям Г. А. Пугаченковой [3]. В этом указателе также дана полная библиография изданий, и в отдельном разделе приведена литература ученых разных стран, посвященная описанию деятельности Г. А. Пугаченковой в области изучения истории искусства Центральной Азии и Узбекистана. Указатель открывается кратким очерком научной, педагогической и общественной деятельности Г. А. Пугаченковой. В этом очерке приводятся основные даты, научные интересы и характеризуется деятельность ученого как археолога, историка, искусствоведа, раскрыта ее работа в качестве руководителя экспедиции Археологических комплексов, охарактеризована ее деятельность в качестве заведующего отделом истории искусств и архитектуры Института искусствознания имени Хамзы. Как ученый с боль- шим опытом, она определяла малоизученные темы и указывала, из каких местностей и какие памятники должны изучаться. Для консультаций по отбору и группировке материала в указателе пригласили специалиста-библиографа библиотеки АН Республики Узбекистан А. А. Викторову, которая также отредактировала это пособие. Во введение к библиографическому пособию включены сведения о биографии ученого и материалы о ее педагогической, общественной деятельности. Труды ученого расположены в хронологическом порядке. Также приведена литература о научной деятельности Г. А. Пугаченковой, В этом указателе представлены научно-популярные статьи Г. А. Пугаченковой по истории искусства Средней Азии и Узбекистана.

Во всех учебных заведениях Узбекистана изучается история страны и история искусства, культуры и памятников, поэтому авторы данных указателей рекомендовали популярные издания Г. А. Пугаченковой в том числе и широкому кругу читателей региона. Научные работы Галины Анатольевны Пугаченковой посвящены изучению древних и средневековых художественных и материальных памятников Средней Азии и соседних стран Ближнего Востока. Она является автором нескольких отдельно изданных книг, представляющих списки материальных и духовных памятников Узбекистана. Совместно с коллегами и учениками она является автором более 700 научных статей, монографий и публикаций, многие из которых были опубликованы на английском, французском, немецком, итальянском и других языках.

В 80-х гг. XX в. она была награждена медалью «За доблестный труд», Государственной премией Хамзы (1966 г.), орденом Беруний (1992 г.), орденом Дружбы (1995 г.) и орденом «За заслуги» (2002 г.). Ее вклад в науку высоко ценится. Г. А. Пугаченкова - единственный узбекский ученый, удостоенный премии «Академическая пальма» французского правительства в 1995 г.

В 1990 г. в честь 75-летия Г. А. Пугаченковой была составлена новая библиография, посвященная ее трудам, опубликованных до 1989 г. [4]. В этом библиографическом справочнике также есть отдельная библиография научно-популярных статей, предназначенная для специалистов и широкого круга читателей.

В 1995 г. к 80-летию со дня рождения Г. А. Пугаченковой был подготовлен библиографический список литературы, изданной этим ученым в 1990-1994 гг. Это пособие подготовлено к публикации Центрально-азиатским институтом археологии Франции [5].

В 2000 г. была издана книга С. Горшениной «Галина Пугаченкова» [6]. Автор в данной книге с 


\section{Т. Д. Байтураев}

документальной точностью представила жизненный путь Г. А. Пугаченковой с детского возраста до конца жизни ученого. В конце этой книги приведена библиография научных изданий Г. А. Пугаченковой, которая всю жизнь изучала археологические памятники Узбекистана, Туркменистана, Афганистана и других стран этого региона. В этом указателе в первом разделе дается библиография всех изданий по хронологии с 1941 по 1999 г. В указателе немало научных работ по древним памятникам архитектуры таких городов, как Бухара, Самарканд, Хива, Коканд, Ташкент и других городов Узбекистана. Многие научные труды написаны совместно с учеными, которые изучали историю, археологию, нумизматику и историю искусства, архитектуры. Среди них такие видные специалисты, как Л. И. Ремпель, Э. В. Ретвеладзе, М. Е. Массон и другие ученые, которые совместно изучали археологические памятники. Это яркое свидетельство того, что Г. А. Пугаченкова знакомилась с научными интересами своих учеников и, стремясь заинтересовать их исследованиями, совместно с ними публиковала работы по материальной и духовной культуре данного региона.

Вот почему ученики с полным основанием, опираясь на научный подход, составляют библиографию изданий Г. А. Пугаченковой. Изучая эти указатели, можно сказать, что издания Г. А. Пугаченковой тщательно библиографировались, начиная с первой статьи 1941 до 1999 г. В этом указателе полностью собраны издания на разных языках и по всем странам, где выходили ее научные труды.

В указателе также даны рецензии на научные монографии, учебные издания, автором которых была Г. А. Пугаченкова, библиографические описания этих изданий приведены на том языке, на котором издавались труды, групировка материала дана в хронологии изданий. Приведен также список научных изданий, которые редактировала Г. А. Пугаченкова, эти издания также даются в хронологическом порядке.

В специальном разделе указаны и сценарии научно-популярных кино- и телефильмов, которые консультировала с точки зрения научной точности академик Г. А. Пугаченкова в процесе их съемки. К ним относятся такие фильмы, как «Город тысячи куполов Хива», «Карши - 2700», «Самарканд» (к 2750-летию города), «Бухара» (к 2500-летию), «Маргилан» (к 1200-летию), фильмы по археологическим памятникам Афрасиаб, Далварзинтепе, по историческим памятникам старого Термеза, короткометражные фильмы по археологическим, архитектурным памятникам Самарканда, Бухары, Шахрисабзя, Хивы, Коканда. Среди них всемирно известные памятники
Самарканда, такие архитектурные памятники, как Регистан, Шахизинд, мечеть и медресе Бибиханум, мавзолей Гур Эмир, обсерватория Улугбека. Сегодня их изучают многие ученые, исследователи, научные работники как в Узбекистане, так и в других странах. Жизнь каждого региона, которые изучала Г. А. Пугаченкова, связана с разными аспектами: это замки правителей, религиозные сооружения, развитие духовной культуры, религия, литература, философия народов, проживающих в этом регионе, в тот период, который изучала она.

Далее в указателе даны книги и статьи об ее участии в подготовке научных кадров. В этой библиографии можно найти список работ, в которых Пугаченкова была научным руководителем аспирантов и докторантов. Группировка материалов приводится по дате защиты кандидатских и докторских диссертаций.

В указателе даны материалы по участию ученого в международных научных мероприятиях. Данный список также формируется по хронологии участия в этих событиях академика Г. А. Пугаченковой. Далее в указателе отмечены ее дипломы, которые она получила в разные годы и за разные заслуги в научной деятельности. Эти дипломы вручены правительствами и научными учреждениями разных стран мира.

Указатели, которые были изданы в разные годы по научным публикациям Г. А. Пугаченковой, снабжены научно-вспомогательными указателями: именными, указателями памятников.

Рассмотренные библиографические указатели дают сведения об истории искусства данного региона. Их читательский адрес очень широк, он может изменяться в зависимости от возраста читателей, их научных интересов, разниться по месту жительства и важности для истории определенной местности, определенного археологического памятника.

Читатели этих изданий могут получать уникальные сведения об истории своего края. Это может быть область, где они живут, или махалля, где поблизости имеются разные археологические памятники культуры. Читатели этих библиографических пособий разнообразны, но основной читатель - это исследователи памятников, перудов, работники научно-исследовательских учреждений, вузов, исследователи истории искусства Узбекистана.

\section{Список литературы}

1. Список научных работ и публикаций заслуженного деятеля науки УзССР, доктора искусствоведения, профессора Г. А. Пугаченковой: к 50-летию со дня рождения и 25летию науч.-исслед. деятельности / Ин-т искусствознания 
им. Хамзы; сост.: П. Ш. Захидов, Ш. С. Ташходжаев. Ташкент: 6. и., 1965. 12 c.

2. Список научных публикаций члена-корреспондента Академии наук УзССР, профессора, доктора искусствоведения, заслуженного деятеля науки УзССР, лауреата Государственной республиканской премии им. Хамзы Г. А. Пугаченковой: к 60-летию со дня рождения и 35летию науч.-исслед. деятельности / Ин-т искусствознания им. Хамзы; сост. Э. В. Ртвеладзе. Ташкент: б. и., 1975. 15 с. Ротапринт.

3. Галина Анатольевна Пугаченкова / АН УзССР, Ин-т искусствознания им. Хамзы, Фундам. 6-ка; сост. Э. В. Ртвеладзе. Ташкент: Фан, 1985. 42 с.

4. Библиография научных работ академика Академии наук Узбекской ССР, доктора искусствоведения, профессора Пугаченковой Галины Анатольевны: к 75-летию ученого / О-во охраны памятников истории и культуры Узбекистана. Ташкент, 1990.53 с.

5. Галина Анатольевна Пугаченкова / Фр. ин-т по изучению Центр. Азии и Ин-та археологии АН Респ. Узбекистан; сост. В. А. Германов. Ташкент, 1995. 17 с.

6. Горшенина С. М. Галина Пугаченкова: перебирая жизни черепки. Ташкент: Изд. фонда «Институт Открытое Общество - Узбекистан», 2000. 254 с.

\section{References}

1. Zakhidov P. Sh. (comp.), Tashkhodzhaev Sh. S. (comp.). List of scientific works and publications of the honored scientist of the Uzbek SSR, Doctor of Art History, professor G. A. Pugachenkova: to the 50th anniversary of the birth and 25th anniversary of sci. research activity / Inst. of Art Studies named after Hamzy. Tashkent, 1965. 11 (in Russ.).

2. Rtveladze E. V. (comp.). List of scientific publications of a corresponding member of the Academy of Sciences of the Uzbek SSR, professor, Doctor of Art History, honored scientist of the Uzbek SSR, laureate of the State Republican Prize named after Khamza G. A. Pugachenkova: to the 60th anniversary of the birth and 35th anniversary of sci. research activity / Inst. of Art Studies named after Hamza. Tashkent, 1975. 15. Rotaprint (in Russ.).

3. Rtveladze E. V. (comp.). Galina Anatolyevna Pugachenkova / Acad. of Sciences of the Uzbek SSR, Inst. of art history named after Hamza, Fundamental library. Tashkent: Fan, 1985.42 (in Russ.).

4. Bibliography of scientific works of academician of the Academy of Sciences of the Uzbek SSR, Doctor of Art History, professor Pugachenkova Galina Anatolyevna: to the 75th anniversary of the scientist / Society for the protection of historical and cultural monuments of Uzbekistan. Tashkent, 1990. 53 (in Russ.).

5. Germanov V. A. (comp.). Galina Anatolyevna Pugachenkova / Fr. Inst. for the Study Central Asia and the Instit. of Archeology of the Acad. of Sciences of the Rep. Uzbekistan. Tashkent, 1995. 17 (in Russ.).

6. Gorshenina S. M. Galina Pugachenkova: going through the life of the shards. Tashkent: Ed. Foundation «Open Society Institute - Uzbekistan», 2002. 254 (in Russ.). 